\title{
Effect of Food Consumption Contain Glutahione Anti-oxidant towards LDL Cholesterol Concentrations on Benzene-exposed-workers at the Romokalisari Shoe Industry, Surabaya
}

\author{
Abdul Rohim Tualeka', Tri Martiana ${ }^{1}$, Ananto Dwi Wibrata ${ }^{2}$, Pudji Rahmawati ${ }^{3}$ \\ ${ }^{1}$ De partment of Occupational Health and Safety, Faculty of Public Health, Airlangga University, 60115 Surabaya, \\ East Java, Indonesia; ' $D$ De partment of Nursing, Health Polytechnics of Ministry Health, Surabaya, Indonesia; \\ ${ }^{3}$ De partment of Development of Islamic Society, State I slamic University Sunan Ampel, Surabaya, Indonesia
}

\begin{abstract}
Background: Benzene is a chemical that is often used in the shoe making industry. Recent studies have shown that benzene can cause a risk of cardiovascular disease by increasing LDL levels in blooda. One efficient intervention is consumption antioxidant-rich foods regularly to reduce blood LDL levels. Research on the effect of LDL cholesterol levels before and after treatment of consumption in benzene-exposed workers is still limited in Indonesia.
\end{abstract}

Methods and Material: A sample of 25 workers with the pre-post test design method. Benzene measurement using the method of NIOSH 1501 with an activated carbon (charcoal) pipe which uses a gaschromatographyflame ionization detector (GC-FID) technique using standard NIOSH 1501. An LDL cholesterol sample is taken by taking blood from a vein in the elbow fold (fossa cubiti). The statistical analysis used was Pearson and Spearman test and Paired t-test.

Result: The majority of respondents have male sex, aged over 50 years. having a high school education background, never wearing a mask while working and having a smoking habit. There is no a difference between the levels of LDL cholesterol in blood before and after consumption food rich in glutathione antioxidants $(p=0107)$ and there is no correlation between the levels of benzene before and after treatment $(\mathrm{p}=0.425 ; \mathrm{p}=0597)$.

Conclusion: There are patterns that vary between LDL cholesterol-rich antioxidants before and after treatment. This can be due to lack time of monitoring in the study, the majority of respondents who still have normal concentration standards and the presence of demographic factors that can influence, for example smoking habit so there is no difference between LDL cholesterol levels before and after treatment. However, workers are recommended to always use PPE, do routine health checks while do physical activity and consume antioxidant-rich foods especially glutahione to prevent cardiovascular risk due to exposure to longterm benzene (more than 10 years).

Keywords: LDL cholesterol, antioxidant, foods, consumption, pre-post test, benzene

Correspondence Author:

Abdul RohimTualeka,

Departement of Occupational Health and Safety, Faculty of Public Health, Airlangga University, 60115

Surabaya, East Java, Indonesia.

E-mail: inzut.tualeka@gmail.com or abdul-r-t@fkm.

unair.ac.id; Tel: +62-31-5920948

\section{Introduction}

The shoe industry is part of the textile and textile products (TPT) industry where there are at least 98,000 units of small and medium enterprises (SMEs) who pursue this industry. Solvents that are widely used in industry, especially the shoe industry, are volatile organic solvents in fat so that organic solvent vapors 
are easily absorbed through the alveolar capillary membrane so that the inhalation process becomes the main pathway for steam exposure produced in the work environment ${ }^{1 .}$ One of these solvents is benzene.

Benzene is one of the aromatic hydrocarbon compounds. Benzene is a liquid that is colorless, evaporates very quickly in the water, and difficult to dissolve in water ${ }^{2}$. Benzene is a raw material for making plastics, resins, synthetic fibers, dyes, and also a component of crude oil ${ }^{3}$. The pathway of benzene exposure to the skin, respiratory tract, and digestive tract ${ }^{4}$.

A person who is exposed to high levels of benzene can experience several signs and symptoms, including drowsiness, dizziness, rapid or irregular heartbeat, headaches, tremors, confusion, unconsciousness, until death ${ }^{5}$. Benzene can cause a decrease in blood cell production which is a result of a spinal cord disruption. Disruption of the blood cells can cause anemia, leukopenia,lymphocytopenia, and can affect the immune system and increase the chance for infection ${ }^{6-7}$. However, currently benzene also has an association in increasing the risk of cardiovascular disease, especially in humans. Research on experimental animals (white mice) showed that inhaled benzene had significantly reduced levels of circulating angiogenic cells (Flk-1 + / Sea- $1+$ ) as well as increased levels of plasma low-density lipoprotein (LDL) ${ }^{8}$. Increased LDL levels in the blood increase the risk of cardiovascular disease. Detoxification of antioxidant-rich foods is one efficient way to reduce cardiovascular effects from benzene such as foods contains of glutahione. The foods rich in glutathione content such as avocado, asparagus, carrots, tomatoes, oranges, and broccoli $i^{9}$ Unfortunately, research on experimentation concerning the effect of giving glutathione antioxidant-rich foods on blood LDL levels still limited in Indonesia. Therefore, this study aims to analyze the effect of giving consumption of glutathione antioxidant-rich foods on blood LDL levels in Shoe Industry workers in the Romokalisari Surabaya.

\section{Method and Materials}

The type of research used is pre-and post test experimental. Subjects are workers in the Tambak Osowilangun industrial shoe in Surabaya. The inclusion criteria in this study were male and female workers who had worked in the shoe industry in Tambak Osowilangun for more than 10 years and were willing to be used as research respondents. The study sample was 25 people.

The variables calculated were benzene levels, LDL levels, consumption of foods rich in glutathione antioxidants. Foods rich in glutathione content such as avocado, asparagus, carrots, tomatoes, oranges, and broccoli ${ }^{9}$. The research subject was chosen by the person who was describing the benefits and incentive of participating in the study. Subjects will be given consumption of glutathione antioxidant-rich foods 3 times a day for 5 days. The following is the enzyme content in each food ${ }^{9} 10$ :

The content of glutathione in avocado $=31.2$
The content of glutathione in asparagus $=26.3$
The content of glutathione in carrots $=5.6$
Glutathione content in toina toes $=10.9$
The content of glutathione in oranges $=10.6$
The content of glutathione in broccoli $=7.8$

The willingness to participate in the study was made in writing through informed consent and this study had received prior ethical approval by the Public Health Faculty Ethics Committee, Airlangga University with ethics number 516 KEP-K.

The measurement of benzene concentration in the work environment using a measurement method of NIOSH 1501 with an activated carbon (charcoal) pipe which uses a gas chromatography-flameionization detector (GC-FID) technique using standard NIOSH 1501 .

Sample LDL cholesterol is taken with way take blood on vessels venous blood on folding elbow (fossa cubiti). After that sample blood The in put into the tube sample blood to be brought to our prolaboratory to be checked LDL levels inside blood.

Data will be presented in the form there are percentages, mean, and standard deviations. Statistical analysis used the Paired t-test to analyze the difference before and after testing (pre-post test) and 
Pearson and Spearman's Rank test with alpha of 0.05 for the correlation between variables with alpha of 0.05 using SPSS version 20 ( SPSS, Inc., Chicago, IL) .

\section{Result}

Characteristics of Respondents in Shoe Industry Workers in Romokalisari Surabaya

Table 1. Demographic Distribution of Respondents in Shoe Industry Workers in the Romokalisari Surabaya $(n=25)$

\begin{tabular}{|l|l|l|}
\hline Variable & $\begin{array}{l}\text { Percentage } \\
(\%)\end{array}$ & Mean \pm SD \\
\hline Gender & 56.00 & $1.44 \pm 0.507$ \\
\hline Male & 44.00 & \\
\hline Female & & \\
\hline Age & 56.00 & $1.44 \pm 0.506$ \\
\hline$<50$ years & 44.00 & \\
\hline$\geq 50$ years & 40.00 & \\
\hline Education & 16.00 & $2.74 \pm 0.541$ \\
\hline Middle School & 44.00 & \\
\hline Junior High School & 52.00 & \\
\hline Senior High School & & \\
\hline $\begin{array}{l}\text { Use of Masks while } \\
\text { Working }\end{array}$ & & \\
\hline Yes, everyday & & \\
\hline Sometimes & & \\
\hline Never & & \\
\hline Smoking Habit & & \\
\hline Never & & \\
\hline Yes & & \\
\hline
\end{tabular}

The majority of respondents have male sex, aged over 50 years. having a high school education background, never wearing a mask while working and having a smoking habit.

Distribution of Benzene Levels in Shoe Industry Workers in Romokalisari Surabaya

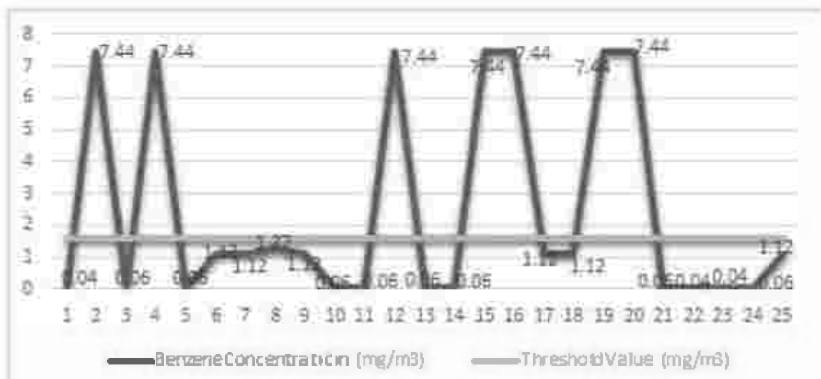

Figure 1. Distribution of Benzene Levels to Shoe Industry Workers in Romokalisari Surabaya $(\mathbf{n}=\mathbf{2 5})$

Figure 1 above shows the concentration of benzene in the Tambak Oso Wilangun industrial shoe. It was seen that most of the respondents were in the work environment with benzene conclusions TLVin the work environment $\left(<1.6 \mathrm{mg} / \mathrm{m}^{3}\right)$ which was 18 respondents.

Before and after consumption of glutathione antioxidant-rich towards levels of LDL cholesterol in Romokalisari Shoe Industry Workers

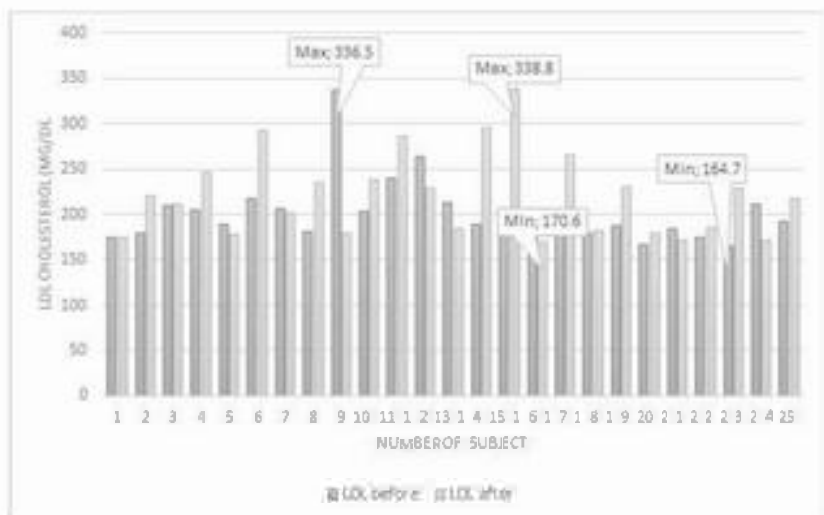

Figure 2. Before and after glutathione antioxidant-rich consumption towards LDL cholesterol in Romokalisari shoe industry workers $(n=25)$

In Figure 2 shows that there are different patterns between LDL levels before and after treatment. In the pre-test the drinking and maximum levels of LDL were $164.7 \mathrm{mg} / \mathrm{dL}$ and $336.5 \mathrm{mg}$ / dL. Whereas, after post test or giving glutahione antioxidant-rich foods, the minumum and maximum LDL were 170.6 $\mathrm{dL}$ and $336.5 \mathrm{dL}$. This pattern irregularity can also be supported by a statistical analysis test which states there is no difference LDL cholesterol levels between before and after consumption glutahione-rich foods ( $p$ $=0.107)$ (Table 2 ) and there was no correlation between benzene levels before and after treatment $(\mathrm{p}=0.425 ; \mathrm{p}$ $=0.597)($ Table 3$)$. 
Table 2. Paired t-test analysis of LDL levels before and after treatment for shoe industry workers in the Romokalisari Surabaya $(n=25)$

\begin{tabular}{|l|c|}
\hline Variable & p-value \\
\cline { 1 - 1 } Pre test (LDL level before treatment) & \multirow{2}{*}{0.107} \\
\cline { 1 - 1 } Post test (LDL level after treatment) & \\
\hline
\end{tabular}

Table 3. Spearman analysis test between Benzene levels with LDL levels before and after treatment in shoe industry workers in the Romokalisari Surabaya $(\mathrm{n}=\mathbf{2 5})$

\begin{tabular}{|l|l|l|}
\hline $\begin{array}{l}\text { Independent } \\
\text { variable }\end{array}$ & Dependent variable & p-value \\
\hline Benzene & $\begin{array}{l}\text { Pre test (LDL level } \\
\text { before treatment) }\end{array}$ & 0.425 \\
\cline { 2 - 3 } & $\begin{array}{l}\text { Post test (LDL level after } \\
\text { treatment) }\end{array}$ & 0.597 \\
\hline
\end{tabular}

\section{Discussion}

The majority of respondents have male sex, aged over 50 years. having a high school education background, never wearing a mask while working and having a smoking habit.

The results show that benzene levels are still below the TLV Indonesia standard by Minister of Manpower and Transmigration number 13 of 2011 which is $(<1.6$ $\mathrm{mg} / \mathrm{m}^{3}$ ) so that it is still at a safe limit ${ }^{11 .}$ Although currently still at safe limits, counseling is needed from now on to always use PPE when working because the longer the exposure to benzene, the higher the risk of health. The results of the interviews at the Industrial site indicate that currently Indonesian shoe workers have experienced minor health complaints such as nausea, dizziness, coughing if too long at work.

The results show that there is a random trend between LDL levels before and after consumption food contain of glutathione antioxidants. This is supported by no correlation between the levels of benzene with LDL levels before and after treatment and no difference between the levels of LDL in the time before and af ter consumption of food contain glutahione. This contrasts with statements and other studies which showed an increase in LDL levels in mice with benzene exposure. Benzene-exposed mice had higher plasma LDL $(34.2 \pm 4.1 \mathrm{mg} / \mathrm{dL})$ than mice breathing filtered air
$(25.6 \pm 3.3 \mathrm{mg} / \mathrm{dL})^{8 .}$ Thisstudy also contradicts the study of Rajasekaran et al., 2004 which states that there is an increase in LDL levels in white mice in decreased GSH antioxidant levels ${ }^{12}$. The administration of glutathione monoester (GME), a dose of $5 \mathrm{mmol} / \mathrm{kg}$ body weight, twice a day, for 30 days, to be treated with 1-buthionineSR-sulfoximine (BSO, $4 \mathrm{mmol} / \mathrm{kg}$ body weight, twice a day, for 30 days) normalized the antioxidant status and prevented the minimal modifications on LDL.

But the difference with the two studies is that the study used experimental animals that were smaller in shape and body than humans that allowed greater absorptive benzene power and faster reaction than humans. Things that cause no difference and correlations can be in the form of samples that are still too small ( 25 samples) which are less able to give generalizations to research, lack or limited time in providing monitoring before and after treatment (only 5 days). This can be supported by other study which shows that smaller animals (30 mice) need 30 days to restore LDL levels to normal and the absence of previous studies on the effects of diet foods rich in antioxidants (especially glutathione) on LDL levels of workers exposed to benzene in the shoe industry and other factors in the form of benzene levels which are still in normal standards and smoking habits ${ }^{12-13}$. Recommendations that can be made even though benzene levels are still normal at this time, this does not guarantee for the next $10-20$ years that it can provide long-term risks to workers so it is recommended to use PPE especially masks, carry out regular health checks (especially funded by companies) and consuming antioxidant-rich foods (especially glutathione) and regularly doing physical activities to prevent cardiovascular disease due to benzene exposure.

\section{Conclusion}

The majority of respondents have male sex, aged over 50 years. having a high school education background, never wearing a mask while working and having a smoking habit. Benzene levels in workers are still at normal limits. There is no difference LDL cholesterol levels between before and after consumption of foods rich in glutahione antioxidants and there is no correlation between benzene levels before and after treatment. Things that affect can be limited monitoring time, a small sample, and there are other factors that are more dominant such as smoking habits . 
Conflict of Interest: All authors have no conflicts of interest to declare.

Source of Funding: This is an article that was supported by Faculty of Public Health, Airlangga University, Indonesia, 2018.

Ethical Clearance: Ethical Clearance taken from Faculty of Public Health number 516/EA/KEPK/2018, Airlangga University, Indonesia

\section{References}

1. La Dou, J. Occupational and Environmental Medicine (Third edit). California, San Francisco: Division of Occupational and Environmental Medicine, Clinical Professor, 2004.

2. Agency for Toxic Substances and Disease Registry (ATSDR). Toxicological Profile For Toluene, Georgia http://www.atsdr.cdc.gov/ toxprofiles, 2000.

3. Smith, Martyn T. Advances in Understanding Benzene Health Effects and Susce ptibility. Division of Environmental Health Sciences, School of Public Health, University of California, Berkeley, Calif ornia, 2010.

4. Putri, YRP. Benzena in Mara Urban. Department of Chemistry, Faculty of Mathematics and Natural Sciences, University of Indonesia, Depok, 2011

5. CDC. Facts about Benzene. Retrieved October 11, 2018, from https://emergency.cdc.gov/agent/ benzene/basics/facts.asp , 2013.

6. Integrated Risk Information System (IRIS). Benzene . Chemical Assessment Summary, 2003.

7. Kamal, A., \& Malik, RN. Hematological evidence of occupational exposure to chemicals and other factors among auto-repair workers in Rawalpindi, Pakistan. Osong public health and research perspectives 2012, 3 (4), 229-238.

8. Abplanalp, W., DeJarnett, N., Riggs, DW, Conklin, DJ, McCracken, JP, Srivastava, S., ... \& O'Toole, TE. Benzene exposure is associated with cardiovascular disease risk. PloS one 2017, 12 (9), e0183602.

9. Hodges, RE, \& Minich , DM Modulation of Metabolic Detoxification Pathways Using Foods and Food-Derived Components: A Scientific Review with Clinical Application. Journal of Nutrition and Metabolism 2015, 2015., 760689. http://doi. org/10.1155/2015/760689

10. Tualeka, Abdul Rohim. Philoso phy of Occupational Health and Safety . Airlangga University Press: Surabaya, 2018.

11. The Republic of Indonesia. Regulation of the Minister of Manpower and Transmigration No. 13 of 2011 concerning the Threshold Value of Physical and Chemical Factors in the Workplace. Jakarta: State Secretariat, 2011. [InIndonesian]

12. Rajasekaran, NS, Sathyanarayanan, S., Devaraj, NS, \& Devaraj , H. Chronic depletion of glutathione (GSH) and minimal modification of LDL in vivo: its prevention by glutathione mono ester (GME) therapy. Biochimica et Biophysica Acta (BBA) -Molecular Basis of Disease 2005, 1741 (1-2), 103-112.

13. Ignatowicz, E., Woźniak, A., Kulza, M., SeńczukPrzybyłowska, M., Cimino, F., Piekoszewski, W. ... \& Florek, E. Exposure to alcohol and tobacco smoke causes oxidative stress in rats. Pharmacological Reports 2013, 65 (4), 906-913. 